\title{
SIFAT FISIK DAN MEKANIK PAPAN PARTIKEL SERAT KULIT BATANG SAGU (Metroxylon sago ROTTB.) BERDASARKAN UKURAN SERAT
}

\author{
(Physical and Mechanical Properties Particle Board of Sago Bark (Metroxylon sago Rottb.) \\ Based on Fiber Size )
}

\author{
Geni Saputri Handayani, M Dirhamsyah, Nurhaida, Dina Setyawati \\ Fakultas Kehutanan Universitas Tanjungpura Pontianak. Jl. Daya Nasional Pontianak 78124 \\ Email : genisaputri29@yahoo.com
}

\begin{abstract}
Wood is the most used basic material for daily life, such as material construction, furniture, appliances, and etcetera. This causes the increase of the necessity of wood in the other hand, the availability of wood are decrasing. On of the solutions for this problem is the particle-board from the agriculture waste which is sago. One of the sago parts which can be used is the sago bark. It contains more number of cellulose and lignin then dago dregs and it also contains bigger cellulose and lignin than woods, so it can be used as particle-board. The fibers used are $5 \mathrm{~cm}, 10 \mathrm{~cm}$, and $15 \mathrm{~cm}$. The citterate solution concentrate is $20 \%$ which was mixed with the particle-board. These particle mixtures were in an oven in 24 hours. The production of particleboard with the target of density $0,6 \mathrm{~g} / \mathrm{cm}^{2}$ and forged in $180^{\circ} \mathrm{C}$ within 15 minutes. The aim of this research is to find out the size of fibers for the particle-board. The best quality of particle board based on JIS 5908 standard is on the $10 \mathrm{~cm}$ fiber, with board mechanical characteristic : the flexibility module $22801,8196 \mathrm{kgf} / \mathrm{cm}^{2}$, the fracture module $334,9006 \mathrm{kgf} / \mathrm{cm}^{2}$, and the screw holding strength $46,5448 \mathrm{kgf} / \mathrm{cm}^{2}$. The physical characteristic of water concentrate $10,6249 \%$ and the water absorption 66,8314\%. The score of dense/thickness development and internal bonding did not quality JIS 5908 A (2008). In general, the result of the research showed that longer the size of fibers the better the quality would be produced.
\end{abstract}

Keywords : fiber size, oven duration, particle-board, sago bark

\section{PENDAHULUAN}

Kebutuhan kayu semakin meningkat sedangkan ketersediaan kayu berkurang. Perlu alternatif lain yaitu pembuatan papan partikel menggunakan limbah pertanian, perkebunan dan limbah kayu solid. Pada penelitian ini menggunakan serat dari kulit batang sagu. Jumlah kulit batang sagu dan ampas sagu adalah sekitar $26 \%$ dan $14 \%$ berdasar bobot total balak sagu (Singhal et al. 2008). Kulit batang sagu mengandung selulosa $(56,86 \%)$ dan lignin yang lebih banyak $(37,70 \%)$ daripada ampas sagu serta kulit batang sagu mengandung selulosa dan lignin besar dibanding kayu (Kiat 2006).
Penelitian papan partikel serat kulit batang sagu menggunakan perlakuan pengovenan terlebih dahulu sebelum kempa panas terhadap bahan yang sudah tercampur dengan perekat, hal ini mengacu pada penelitian Dewi et al, (2015) yang mana campuran serat kotoran gajah dan asam sitrat yang dikering ovenkan 18 jam terlebih dahulu sebelum dikempa dan Wahyudi et al (2015) yang menggunakan oven 24 jam dalam penelitiannya karakteristik papan sedang kayu skubang menggunakan asam malat. Pengovenan terlebih dahulu sebelum dikempa panas ini bertujuan agar kadar air yang terdapat 
dalam serat kulit batang sagu rendah, sehingga asam sitrat yang dijadikan perekat meresap kedalam serat, karena apabila kadar air bahan masih tinggi akan menyebabkan perekat susah masuk sehingga mempengaruhi sifat fisik dan mekanik papan. Selain itu, ukuran serat juga mampu mempengaruhi mempengaruhi sifat fisik dan mekanik papan partikel. Semakin panjang serat maka kekuatan papan akan semakin baik. Papan partikel serat kulit batang sagu ini belum diketahui ukuran serat yang terbaik terhadap kualitas papan partikel serta yang memenuhi standar JIS A 5908-2003, sehingga perlu dilakukan penelitian dan pengujian terhadap papan partikel dari serat kulit batang sagu.

\section{METODE PENELITIAN}

Penelitian ini dilaksanakan di Laboratorium Pengolahan Kayu Fakultas Kehutanan Universitas Tanjungpura sebagai tempat persiapan serat kulit batang sagu, pencampuran bahan dengan asam sitrat dan pengujian sifat fisik dan di Laboratorium PT. Duta Pertiwi Nusantara sebagai tempat pembuatan papan partikel dan pengujian sifat mekanik papan partikel. Bahan yang digunakan pada penelitian ini yaitu serat kulit batang sagu. Alat utama yang digunakan gunting, penggaris, hotplate, gelas ukur, caliper, timbangan analitik, oven, universal testing machine, mesin bor dan pistol lem. Perekat yang digunakan yaitu asam sitrat dengan jumlah perekat yang digunakan $20 \%$.

\section{Persiapan Bahan Baku}

Limbah kulit batang sagu dibersihkan, kemudian direndam kurang lebih 30 menit, kemudian dijemur selama kurang lebih 2 minggu. Setelah itu dioven sampai mencapai KA 7\%. Potong menjadi ukuran $5 \mathrm{~cm}, 10 \mathrm{~cm}$ dan $15 \mathrm{~cm}$.

\section{Pembuatan Papan Partikel}

Partikel yang sudah dipotong dicampur dengan asam sitrat, sebelumnya asam sitrat dilarutkan menggunakan air sampai suhu $60^{\circ} \mathrm{C}$. Campuran partikel dan asam sitrat tadi di oven selama 24 jam. Setelah itu disusun dalam cetak yang berukuran $30 \mathrm{~cm} \times 30 \mathrm{~cm} \times 1 \mathrm{~cm}$, kemudian dikempa panas dengan suhu $180^{\circ} \mathrm{C}$ selama 15 menit (Widyorini et al, 2015). Papan partikel kemudian dikondisikan selama kurang lebih satu minggu. Selanjutnya dilakukan pengujian sifat fisik dan mekanik terhadap papan partikel sehingga didapat papan partikel terbaik. Parameter sifat fisik yang diuji meliputi kerapatan, kadar air, pengembangan tebal dan daya serap air. Sementara sifat mekanik meliputi kekuatan Lentur (MOE) dan kekuatan patah (MOR). Penelitian ini menggunakan percobaan Rancangan Acak Lengkap (RAL) dengan 3 kali ulangan. Pengujian dilakukan berdasarkan standar JIS 5908 A (2003).

\section{HASIL DAN PEMBAHASAN}

Papan partikel serat kulit batang sagu dengan ukuran serat $5 \mathrm{~cm}, 10 \mathrm{~cm}$ dan 15 cm dapat dilihat pada Gambar 1. dibawah 


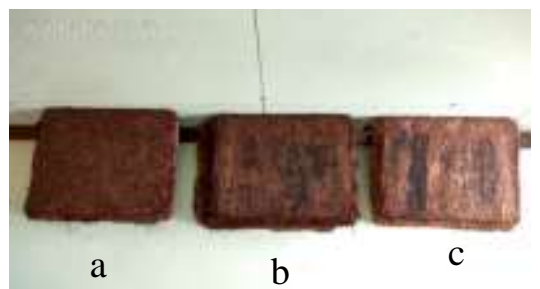

Gambar 1. Papan Partikel Serat Kulit Batang Sagu : a. ukuran serat 5 cm ; b. ukuran serat 10 cm ; c. ukuran serat $15 \mathrm{~cm}$

Kerapatan

Nilai kerapatan papan partikel berkisar $0,8854-0,5725 \mathrm{gr} / \mathrm{cm}^{3}$. Nilai kerapatan papan partikel yang dihasilkan sudah memenuhi standar JIS A 59082003 .

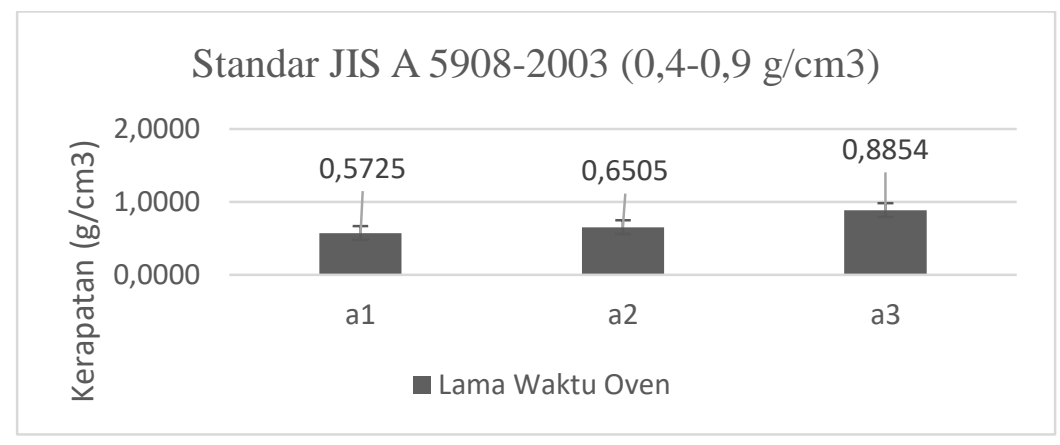

Gambar 2. Nilai Rata- rata Kerapatan Papan Partikel (Average of Density of Particle Board)

Hasil sidik ragam menunjukan bahwa ukuran serat memberikan pengaruh nyata kepada kerapatan papan partikel. Faktor yang berpengaruh pada kerapatan papan partikel serat kulit batang sagu ialah faktor ukuran serat, dimana nilai kerapatan tertinggi pada ukuran serat $15 \mathrm{~cm}$, hal ini disebabkan oleh ukuran serat yang panjang kerapatan akan semakin tinggi sebagaimana yang dinyatakan oleh Suroto (2010) dalam penelitiannya menggunakan limbah serutan rotan dimana semakin tinggi konsentrasi perekat dan semakin panjang ukuran potongan partikel kerapatan semakin tinggi, karena semakin panjang potongan partikel mengakibatkan semakin luasnya permukaan yang saling mengait antar partikel sehingga papan lebih padat. Setiawan (2008) menyebutkan salah satu faktor kerapatan ialah panjang serat, semakin panjang ukuran serat maka kerapatan papan akan semakin tinggi.

\section{Kadar Air}

Nilai Kadar air papan partikel tertinggi berkisar 18,8306- 10,6249\% . Nilai kadar air papan partikel untuk ukuran serat $5 \mathrm{~cm}$ dan $10 \mathrm{~cm}$ memenuhi standar JIS, sedangkan $15 \mathrm{~cm}$ melewati batas standar JIS. 


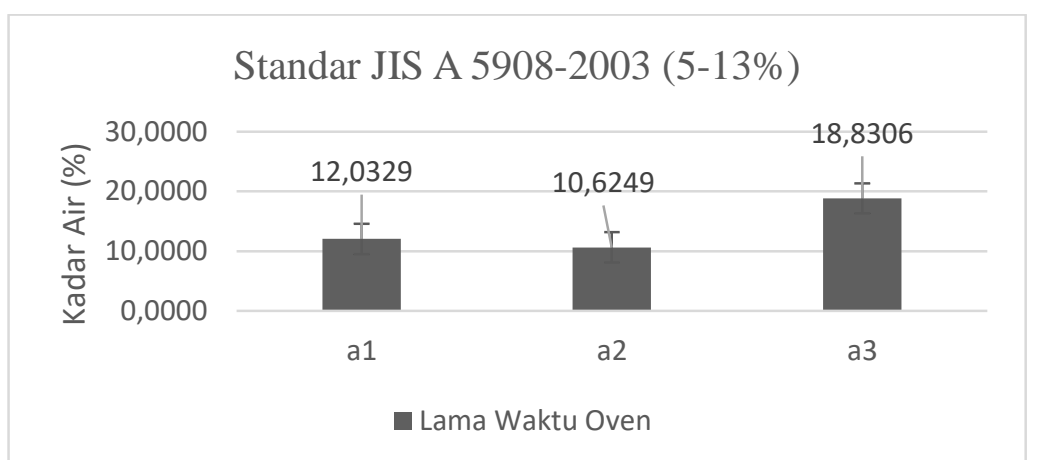

Gambar 3. Nilai Rata-rata Kadar Air Papan Partikel (Average of Moisture Content of Particle Board)

Semakin rendah kadar air papan partikel serat maka papan partikel maka kualitas yang dihasilkan semakin baik. Hasil sidik ragam menunjukan bahwa ukuran serat memberikan pengaruh nyata kepada kadar air papan partikel Kadar air terbaik dihasilkan oleh papan partikel dengan ukurran serat $10 \mathrm{~cm}$, sedangkan kadar air tertinggi pada Histogram diatas terdapat pada ukuran $15 \mathrm{~cm}$. Hal ini kemungkinan disebabkan oleh ukuran serat yang panjang sehingga penyusunan serat lebih susah dan menyebabkan serat tidak merata, sebagaimana yang disebutkan oleh Sumimi et al (2016) penyusunan bahan baku yang tidak merata pada saat pembuatan papan sehingga bahan baku menumpuk pada satu titik dan terjadi celah atau rongga antar serat. Disamping itu juga dipengaruhi oleh lama pengovenan sebelum kempa panas. Campuran bahan partikel semakin lama dioven partikel akan menjadi lebih kering, sehingga setelah dikempa hal ini mempengaruhi kadar air papan dan terjadi kerusakan terhadap partikel.

\section{Daya Serap Air}

Nilai daya serap air papan partikel berkisar 72.0338-55,9133\%. Hasil sidik ragam menunjukan bahwa ukuran serat memberikan pengaruh nyata kepada daya serap air papan partikel.

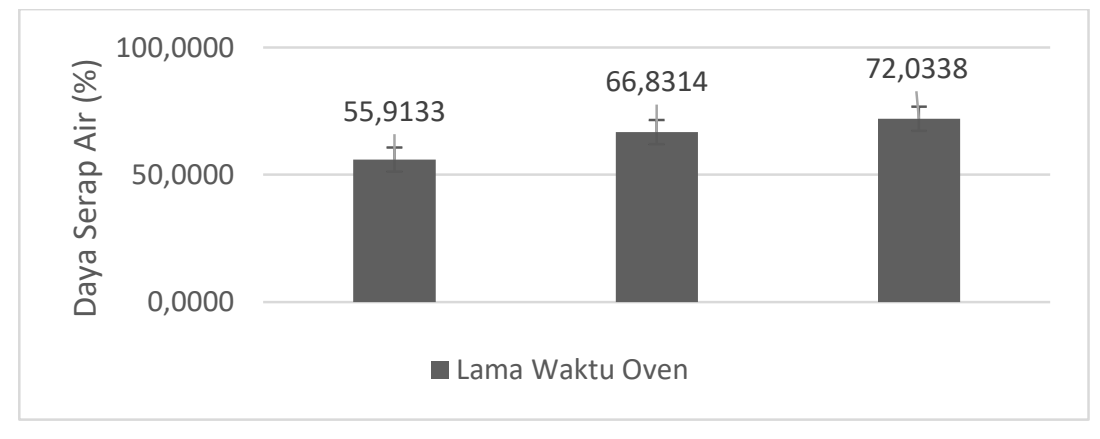

Gambar 4. Nilai Rata-rata Daya Serap Air Papan Partikel (Average of Water Absorption of Particle Board)

Histogram diatas dapat dilihat maka daya serap air yang dihasilkan bahwa semakin panjang ukuran serat semakin tinggi. Faktor yang 
berpengaruh pada daya serap air pada papan partikel serat kulit batang sagu ialah ukuran serat. Daya serap air pada papan berukuran $5 \mathrm{~cm}$ mempunyai daya serap yang lebih rendah dari. hal ini disebabkan oleh ukuran serat dari papan. Ukuran serat yang pendek akan memudahkan dalam penyusunan serat sehingga papan menjadi padat, sedangkan ukuran serat yang panjang akan menyebabkan penyusunan serat yang susah sehingga papan tidak menjadi padat dan air yang masuk lebih banyak, sebagaimana pernyataan Roza (2009) papan partikel sangat mudah menyerap air pada arah tebal terutama pada keadaan basah dan suhu yang lembab. Sehingga dapat disimpulkan dari histogram diatas bahwa papan partikel terbaik dihasilkan oleh papan berukuran $5 \mathrm{~cm}$.

\section{Pengembangan Tebal}

Nilai pengembangan tebal papan partikel berkisar 20.8407-13,4327 \% , untuk nilai pengembangan tebal papan partikel semua ukuran serat melewati batas standar JIS A 5908-2003. Hasil sidik ragam menunjukan bahwa ukuran serat memberikan pengaruh nyata kepada pengembangan tebal papan partikel.

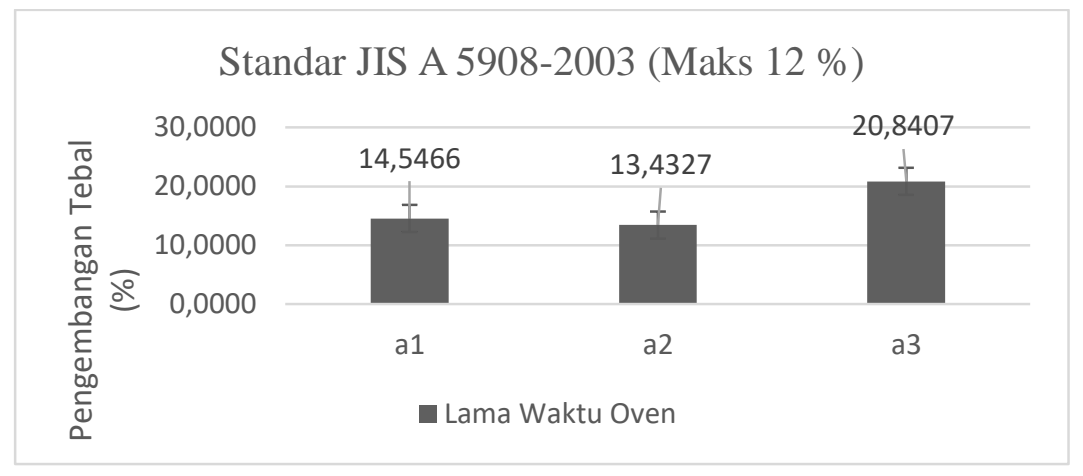

Gambar 5. Nilai Rata-rata Pengembangan Tebal Papan Partikel (Average of Thickness Swelling of Particle Board)

Histogram diatas dapat dilihat bahwa ukuran serat yang optimal dan menghasilkan papan pengembangan tebal terbaik pada ukuran $10 \mathrm{~cm}$, karena ukuran serat penyusunan akan lebih mudah dan sama rata sehingga papan menjadi padat dan air masuk lebih sedikit. Sedangkan untuk serat yang panjang pengembangan tebal papan lebih tinggi, sebagaimana yang dinyatakan oleh Budiadji (2004) bahwa semakin besar ukuran partikel maka akan semakin banyak penyerapan air begitu pula sebaliknya. Disamping itu hal ini juga diduga disebabkan oleh perekat yang hanya menutupi permukaan serat, tetapi tidak masuk kedalam serat, sehingga pada saat perendaman air masuk melalui ujungujung serat ke arah memanjang yang menyebabkan pengembangan tebal menjadi besar (Prasetyo et al, 2010). Sedangkan untuk ukuran serat $5 \mathrm{~cm}$ pengembangan tebal juga tinggi, diduga ukuran serat yang terlalu pendek sehingga menyebabkan antar serat tidak 
saling mengikat,hal ini menyebabkan papan tidak padat serta terdapat rongga dan air mudah masuk.

\section{Modulus of elasticity (MOE)}

Nilai MOE papan partikel berkisar 22801,8196-9583,0724 kgf/ $\mathrm{cm}^{2}$. Nilai MOE papan hanya serat ukuran $10 \mathrm{~cm}$ yang memenuhi standar JIS A 59082003, sedangkan serat lain tidak memenuhi standar. Hasil sidik ragam menunjukan bahwa ukuran serat memberikan pengaruh nyata kepada MOE papan partikel.

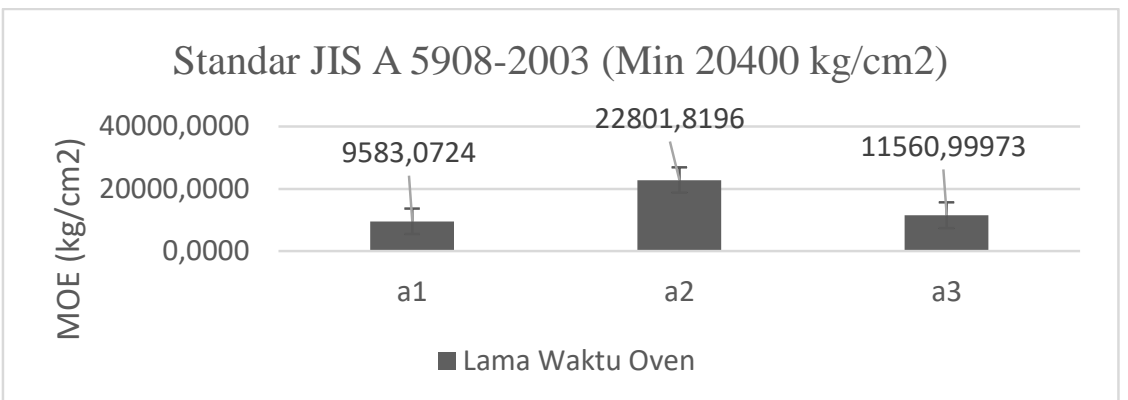

Gambar 6. Nilai Rata-rata MOE Papan Partikel (Average of Modulus of Elastisity (MOE) of Particle Board)

$\begin{array}{lll}\text { Maloney (1993) menyatakan } & \text { dalam pola penyusunan. Penyusunan } \\ \text { kekuatan lentur suatu papan } & \text { dalam penelitian ini menggunakan } \\ \text { dipengaruhi oleh kandungan dan jenis } & \text { manual sehingga serat yang disusun } \\ \text { perekat, daya ikat rekat dan panjang } & \text { tidak merata dan padat. Sedangkan } \\ \text { serat. Semakin panjang potongan } & \text { untuk lama waktu oven secara umum } \\ \text { partikel maka MOE yang dihasilkan } & \text { papan tanpa oven menghasilkan MOE } \\ \text { semakin tinggi karena ukuran yang } & \text { lebih tinggi. Sehingga dapat dilihat } \\ \text { panjang mengakibatkan semakin } & \text { bahwa ukuran serat 10 cm } \\ \text { luasnya bidang saling kait mengait antar } & \text { menghasilkan papan yang lebih baik. } \\ \text { partikel, sebaliknya semakin pendek } & \text { Modulus of rupture (MOR) } \\ \text { maka semakin kecil keterkaitan antar } & \text { Nilai MOR yang dihasilkan berkisar } \\ \text { partikel (Suroto, 2010). Namun, pada } & \text { 334,9006-78,5371 kg/cm }{ }^{2} \text { Nilai MOR } \\ \text { ukuran partikel 15 cm MOE yang } & \text { papan partikel memenuhi standar JIS A } \\ \text { dihasilkan lebih rendah dari pada MOE } & \text { 5908-2003. Hasil sidik ragam } \\ \text { pada ukuran 10 cm, diduga dipengaruhi } & \text { menunjukan bahwa ukuran serat } \\ \text { oleh ukuran serat yang terlalu panjang. } & \text { memberikan pengaruh nyata kepada } \\ \text { Serat yang panjang akan menyulitkan } & \text { MOR papan partikel }\end{array}$




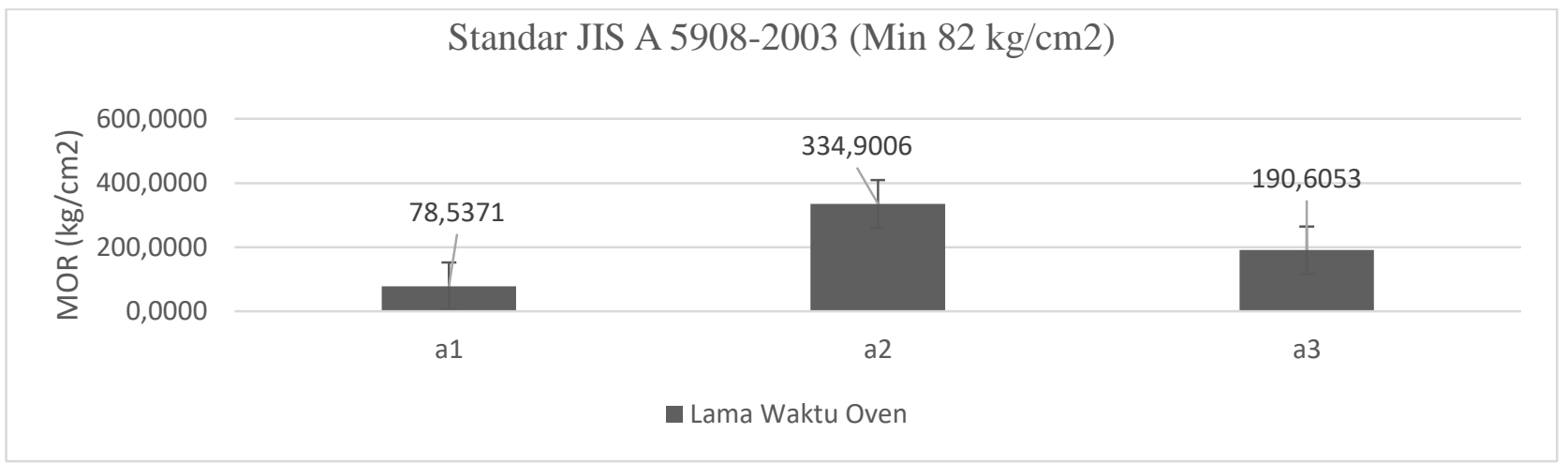

Gambar 7. Nilai Rata-rata MOR Papan Partikel (Average of Modulus of Rupture (MOR) of Particle Board)

Besarnya nilai MOR juga dipengaruhi oleh ukuran serat dan kerapatan serat dan benyaknya rongga udara dalam kayu. (Gunawan et al 2016). Sutrisno (2014), menyatakan semakin panjang serat kayu akan memperluas permukaan ikatan antar serat sehingga menghasilkan jalinan antar serat yang lebih kuat akan tetapi MOR mengalami penurunan pada partikel $15 \mathrm{~cm}$, hal ini disebabkan ukuran serat panjang lebih susah dalam pola penyusunannya sehingga terdapat rongga dan dapat mengurangi sifat mekanik papan (Gunawan et al, 2016) dengan demikian papan partikel dengan ukuran $10 \mathrm{~cm}$ ini lebih ideal untuk digunakan.

\section{Keteguhan Rekat (Internal Bonding =} IB)

Nilai keteguhan papan berkisar $1,4432-1,2004 \mathrm{kgf} / \mathrm{cm}^{2}$. Nilai keteguhan rekat papan tidak memenuhi standar JIS A 5908-2003.

Hasil sidik ragam menunjukan bahwa ukuran serat memberikan pengaruh nyata kepada keteguhan rekat papan partikel.

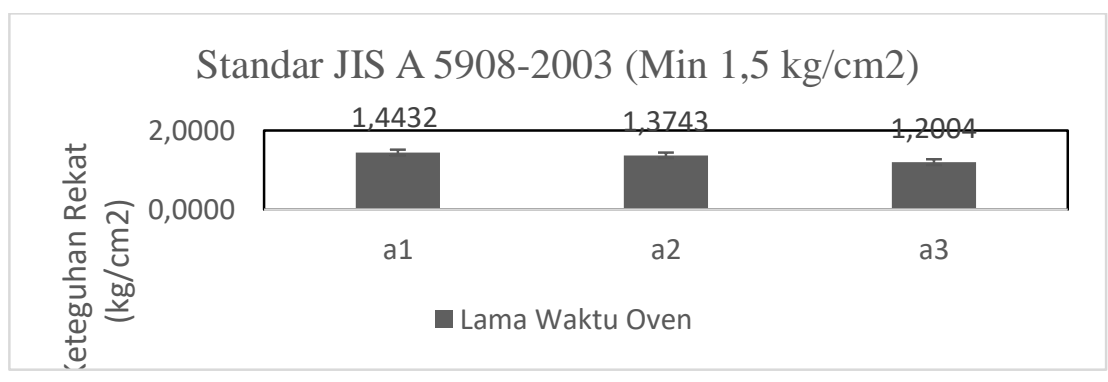

\section{Gambar 8. Nilai Rata-rata Keteguhan Rekat Papan Partikel (Average of Internal Bonding of Particle Board)}

Maloney (1993) menyebutkan ukuran partikel yang kecil akan memberikan ikatan yang kompak dalam membentuk lapisan partikel dan mengurangi adanya ruang kosong sehingga keteguhan rekat papan partikel menjadi tinggi. Sedangkan papan partikel dengan ukuran serat yang panjang mempunyai keteguhan rekat yang rendah karena faktor penyusunan 
partikel yang tidak merata, sehingga perekat yang masuk juga tidak merata, sebagaimana yang disebutkan Umemura, et al. (2010) rendahnya nilai kekuatan internal papan dengan perekat asam sitrat dikarenakan ikatan antara serat dengan asam sitrat tidak optimal. Pengaruh lama waktu oven yaitu semakin lama waktu oven maka semakin baik, hal ini karena kadar air yang terkandung dalam partikel rendah sehingga perekat mudah masuk dan mengisi setiap rongga pertikel (Kusumah, 2015).

\section{Kuat Pegang Sekrup}

Nilai kuat pegang sekrup papan partikel 46,5448-32,7400 kgf, dan memenuhi standar JIS A 5908-2003. Hasil sidik ragam menunjukan bahwa ukuran serat memberikan pengaruh nyata kepada kuat pegang sekrup papan partikel

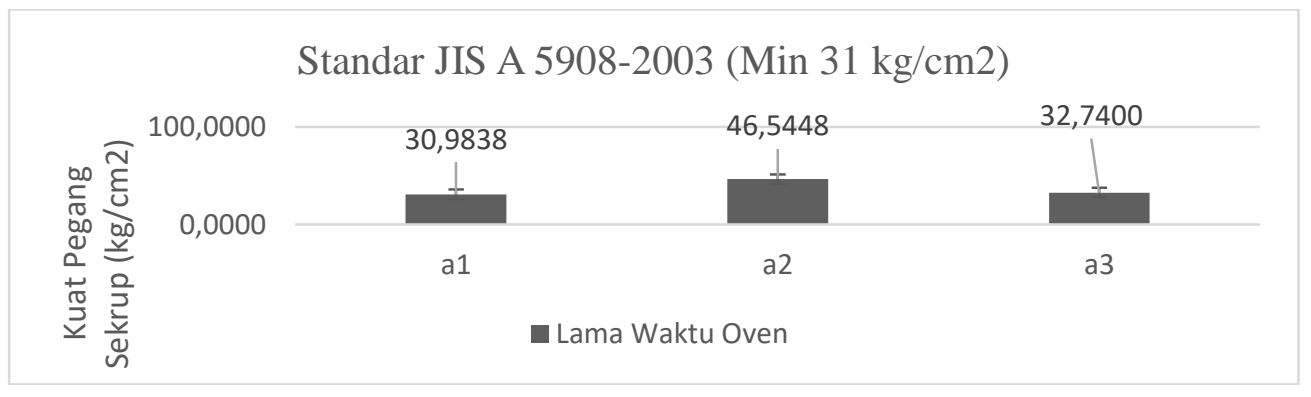

\section{Gambar 9. Nilai Rata-rata Kuat Pegang Sekrup Papan Partikel (Average of Strong Hold The} Screws of Particle Board)

Rita (2015) menyatakan hal ini di pengaruhi oleh beberapa faktor diantaranya pengaruh dari struktur kayu yang digunakan, ukuran serat dan atau partikel, jenis kayu (berat jenis terendah atau tinggi) dan jenis perekat yang digunakan. Secara umum kuat pegang sekrup papan partikel serat kulit batang sagu, ukuran partikel yang lebih pendek menghasilkan keteguhan cabut sekrup yang lebih tinggi dibandingkan partikel yang ukuran serat yang panjang, hal ini karena penyusunan serat yng lebih pendek lebih mudah dan rapi, sehingga papan lebih padat dan rongga antar partikel kecil. Ukuran serat yang panjang penyusunanya lebih sulit, sehingga partikel tidak merata dan menyebabkan rongga antar partikel.
Menurut Prasetyo et al. (2010) kurang rapatnya dan kompaknya serat dengan dapat mempengaruhi nilai kuat pegang sekrup papan partikel. Sehingga ukuran yang lebih optimal terdapat pada ukuran $10 \mathrm{~cm}$. Pengaruh lainnya yaitu lama waktu oven semakin lama waktu oven maka kuat pegang sekrup yang dihasilkan semakin tinggi.

\section{KESIMPULAN}

Hasil dari penelitian diatas dapat disimpulkan bahwa ukuran serat mempengaruhi sifat fisik dan mekanik papan partikel serat kulit batang sagu, dengan ukuran terbaik pada serat $10 \mathrm{~cm}$. Hasil pengujian papan partikel serat kulit batang sagu hanya internal bonding yang tidak memenuhi standar JIS A 59082003. 


\section{SARAN}

1. Perlu dilakukan modifikasi lama waktu oven untuk meningkatkan sifat fisik dan mekanik papan partikel serat kulit batang sagu.

2. Perlu dilakukan pengujian terhadap parameter lain yaitu uji terhadap rayap dan jamur

DAFTAR PUSTAKA

Budiadji, 2004. Sifat Fisik dan Mekanis Papan Partikel Serabut Buah Kelapa Sawit (Elais Guinensis Jack) dengan Campuran Limbah Plastik Jenis PE (Polyethlene). Fakultas Kehutanan Unlam. Banjarbaru.

Dewi, GK. Widyorini, R. Tejolaksono, MN. \& Jati, AS. 2015. Peningkatan Sifat Fisika dan Mekanika Papan Komposit Serat Kotoran Gajah dengan Penambahan Aasam Sitrat. Prosiding Seminar Masyarakat Peneliti Kayu Indonesia (MAPEKI XVIII). Bandung, 4-5 November 2015.

Kusumah, S. S., Ruslan, Daud, M., Wahyuni, I., Darmawan, T., Amin, Y., \& Subiyanto, B. 2010. Pengempangan Papan Komposit dari Limbah Perkebunan Sagu (Metroxylon sago Rottb). J Ilmu dan Teknologi. Кауи Tropis. Vol.8, No.2, 145-154.

Maloney TM. 1993. Modern Particleboard and Dry Process Fiberboard Manufacturing. Miller Freeman Inc. San Francisco.

Prasetyo KW, Henny C, dan Ismadi. 2010. Karakteristik Papan Komposit dari Kenaf (Hibiscus cannabinus L) Hasil Budaya di
Lahan Bekas Penambangan Timah (Kolong) Pulai Bangka Provinsi Bangka Belitung. Prosiding Seminar Masyarakat peneliti kayu Indonesia (MAPEKI XIII), Bali 10-11 November 2010.

Rita R. 2015. Sifat Fisik dan Mekanik Papan Komposit dari Batang Singkong dan Limbah Plastik berdasarkan Pelapisan dan Komposisi Bahan Baku. Jurnal Hutan Lestari. Vol 3, No.2, 337346.

Roza I. 2009. Pengaruh Perbedaan Proses Penyediaan Serat dengan Cara Mekanis Limbah Tandan Kosong Sawit terhadap Papan Serat. Saintek. Vol. XII, No.1, Universitas Muhammadiyah Suumatera Barat, Padang

Setiawan B. 2008. Papan Partikel dari Sekam Padi. Bogor: Fakultas Kehutanan, Institut Pertanian Bogor.

Sumimi, Diba F, Nurhaida, dan Setyawati D. 2016 Kualitas Papan Komposit Kulit Batang Sagu (Metroxylon sp) dan Limbah Plastik Polipropilena Berdasarkan Penambhana Compatibilizer. Jurnal Hutan Lestari. Vol 4, No.4, 570-579.

Suroto.2010. Pengaruh Ukuran dan Konsentrasi Perekat terhadap Sifat Fisik dan Mekanik Papan Partikel Limbah Rotan. Peneliti Baristand Industri Banjarbaru. Jurnal Riset Industri Hasil Hutan. Vol. 2, No.2, 18-30.

Sutrisno, E. \& A.Wahyudi .2017. Karakteristik Pot Organik Berbahan Dasar Limbah Perkebunan Kelapa Sawit. Balai 
Penelitian Teknologi Serat Tanaman Hutan. Kampar.

Umemura, K, Tomohide U., Sasa Sofyan Munawar, Shuichi Kawai. 2010. New Woodbased Molding by using Citric Acid as an Adhesive. J. of Adhesion (Submitted).

Wahyudi A, Prayitno T.A, dan Widyorini R. 2015. Karakteristik Papan Serat Kerapatan Sedang Kayu Skubang (Macaranga gigantea) dengan Perekat Asam Malat. Prosiding Seminar Masyarakat Peneliti Kayu Indonesia (MAPEKI XVIII). Bandung, 4-5 November 2015.

Widyorini R, dan Nugraha AP. 2015. Sifat Fisik dan Mekanis Papan Partikel Sengon dengan Perekat Asam Sitrat-Sukrosa. Jurnal Ilmu Teknologi Kayu Tropis. Vol.13, No.2, 175-184. 